ENTREPRENEURSHIP AND SUSTAINABILITY ISSUES

ISSN 2345-0282 (online) http://jssidoi.org/jesi/

2021 Volume 8 Number 3 (March)

http://doi.org/10.9770/jesi.2021.8.3(17)
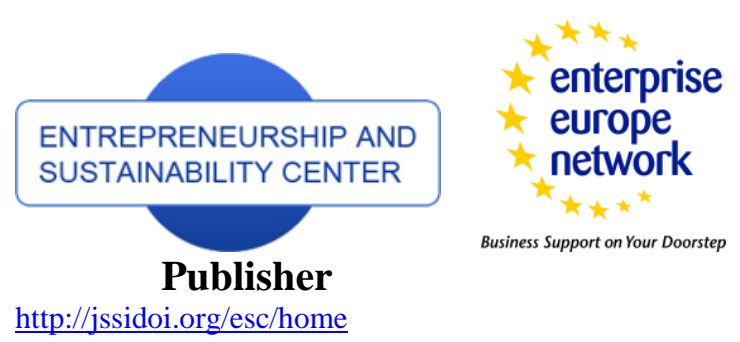

CASPA

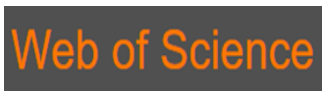

http://jssidoi.org/esc/home

Business Support on Your Doorstep

\title{
VENTURE CAPITAL CHALLENGES IN SAUDI ARABIA
}

\author{
Kamran Ahmed Siddiqui ${ }^{1}$, Mohammad Emad Al-Shaikh ${ }^{2}$, Ishtiaq Ahmed Bajwa ${ }^{3}$ Omar Alenzi ${ }^{4}$ \\ ${ }_{1,2,3}$ \& 4 College of Business Administration, Imam Abdulrahman Bin Faisal University, Dammam, Saudi Arabia \\ E-mails: ${ }^{1}$ KASiddiqui@iau.edu.sa, ${ }^{2}$ IABajwa@iau.edu.sa, ${ }^{3}$ MEAlshaikh@iau.edu.sa, ${ }^{4}$ OAlenzi@iau.edu.sa
}

Received 19 September 2020; accepted 10 December 2020; published 12 January 2021

\begin{abstract}
The purpose of this exploratory research is to highlight the major Venture Capital (VC) Challenges in Saudi Arabia. A survey design using a questionnaire has been selected for this study. The respondents include entrepreneurs, investors, employees of VC firms, investment bankers, and other relevant groups. They answered the questionnaire for their problems, challenges, and prospects about venture capital in Saudi Arabia. A judgmental sample technique was employed to collect the data (N=122). Descriptive analysis using mean comparisons show the top three VC challenges, including 'lack of government support for VC'; 'bureaucratic procedures related to $\mathrm{VC}^{\prime}$ and 'access to angel investors (funding without collateral).' Exploratory Factor Analyses show VC challenges can be grouped into six broader factors, including 'entrepreneurial ecosystem,' 'entrepreneurial culture', 'entrepreneurial attitudes', 'entrepreneurial mindset', 'entrepreneurial finance', 'entrepreneurial planning'. The research provides numerous recommendations to authorities and discusses the need for further research.
\end{abstract}

Keywords: Venture capital; Angel investors; Entrepreneurial Finance; Entrepreneurship; Saudi Arabia

Reference to this paper should be made as follows: Siddiqui, K.A., Al-Shaikh, M.E., Ahmed Bajwa, I., Alenzi, O. 2021. Venture capital challenges in Saudi Arabia. Entrepreneurship and Sustainability Issues, 8(3), 291-302. http://doi.org/10.9770/jesi.2021.8.3(17)

JEL Classifications: L26

\section{Introduction}

Many startups require assistance in various forms to pick up and fit well into the sector where they operate. A suitable way of helping the different groups entering into the business sector afresh is to offer them funding at early and seed stages. In this regard, the operations and terms and conditions of venture capital remained quite successful (Rind, 1981). Venture capital is a form of private equity or financing offered to small companies or business foundations, usually at the beginning of their operations by larger firms or financial institutions. A startup qualifying for venture capital must prove-beyond doubt that it can enlarge to become a competitive player or must have depicted significant growth in areas such as annual revenue, growth, and development of the workers, marketing, or in all these areas (Scheela \& Chua, 2003). The primary reason for the investment by venture capital firms is to acquire equity or some stake at a new startup (Cornelius, 2005). The venture capital's overall role in driving innovation in society and contributing to the economy's development is widely identified and applauded see. (Dossani \& Kenney, 2002; Gilson, 2003; Gu \& Qian, 2019; Sahlman, 1990). Similarly, its contribution to promoting the entrepreneurial environment is also well-recognized (Samila \& Sorenson, 2011; Tian, 2012). On the other hand, due to their unique features, the role of close-end venture capital for early-stage 


\section{ENTREPRENEURSHIP AND SUSTAINABILITY ISSUES}

ISSN 2345-0282 (online) http://jssidoi.org/jesi/

2021 Volume 8 Number 3 (March)

http://doi.org/10.9770/jesi.2021.8.3(17)

startup financing and sustainable venture capital importance for the sustainable startup is also emphasized (Bocken, 2015; Bonini \& Capizzi, 2019). Another area that gained attention for researchers and policymakers in venture capital literature is the operational and other types of challenges faced by venture capitals in various countries. Nevertheless, venture capital firms' critical importance in the funding ecosystem requires the country's economic managers to pay attention to VCs' problems and challenges. In this regard, various studies highlighted numerous issues faced by venture capital firms in different countries. For example, Murray (1992) for UK, Campani et al. (2016) for Brazil, Jones and Mlambo (2013) for South Africa, Scheela and Van Dinh (2004) for Vietnam, Dauterive \& Fok (2004), Zhang (2017) for the Chinese market, Rossi (2015) for Italy and Aberman (2009) for the USA. However, no comprehensive research is available examining the role, awareness, and challenges/problems faced by venture capital firms in KSA. This study aims to bridge this gap and focus on the venture capital market of Saudi Arabia.

\section{Literature Review}

The venture capitalists usually take the risk of investing in the new business operation with the belief that the business they support will record impressive performance. The factors that generally appeal to the venture capitalists and drive them to invest in the startups are that such companies usually rely on technological and innovative ways of functioning. Further, these startups also tend to use some modern business models that are highly likely to yield the best outcome when applied to the appropriate forms (Scheela \& Chua, 2003). Venture capitals are one of the main contributors to innovative entrepreneurship in an economy ultimately effecting the social development.

Globally, venture capitalists tend to differ in their reasons for providing funding. One of the significant reasons facilitating venture capitalists' actions is the business condition (Cornelius, 2005). Whereas some VCs may choose to invest in new ideas or startups, others opt to invest in existing firms that only require some support to expand and reach global levels. Some venture capitalists may also strictly choose to invest in specific sectors depending on their interest or specialization. The other funding motivation for VCs at the global level is that some opt to invest their money in local firms. In contrast, others may choose to invest in companies operating at international levels (Cornelius, 2005). The U.S. dominates the global venture capital investment. Samuel (2017) states that the U.S.'s total investment accumulates to $\$ 21.5$ billion surpassing Asia, which stood second with $\$ 12.3$ billion. Europe is third in the VC list, with a total investment amounting to $\$ 4.7$ (Samuel, 2017).

Regarding the difference between venture capital and other similar financing sources, it is critical to understand that although both venture capital and angel investors are funding methods for new or startup businesses, still, there are differences between them (Bonnet \& Wirtz, 2011). Nevertheless, venture capitalists are more likely to have more experience and professionalism in evaluating and managing business or money. On the other hand, angel investors are mostly educated and experienced investors; in addition to that, they typically have good knowledge in several fields with more general backgrounds or experiences (Bellavitis et al., 2017; Van Osnabrugge, 2000). Similarly, these days it is also important to differentiate between Crowdfunding and venture capital financing. According to the Securities and Exchange Commission, USA, "Crowdfunding generally refers to a financing method in which money is raised through soliciting relatively small individual investments or contributions from a large number of people. Likewise, in recent times Crowdfunding is one of the financing types to raise capital for new ventures of small existing ventures, and its role is increasing. (Capizzi \& Carluccio, 2016; Marchand, 2016). Furthermore, one of the key differences between VCs and Crowdfunding is the monitoring process after funding. In venture capital, enterprises' operations and management are well-monitored, whereas such a requirement does not exist in Crowdfunding. On the other hand, the stability of enterprises in VCs is relatively better than stability in crowdfunding enterprises. In Crowdfunding, clear objectives or obligations are not existing, especially in (donation-based type) while, in VCs, the agreement is between founder/entrepreneur and venture capital for specific goals. (Mamonov Malaga, \& Rosenblum, 2017).

The venture capital sector traces its origin in the U.S; the concept of venture capital is long being used for startup financing in the USA, making them a pioneer. However, it is fast developing in other countries. Although there are several common grounds between the working of 'Mudarabah,' the Islamic finance instrument, and the 


\section{ENTREPRENEURSHIP AND SUSTAINABILITY ISSUES}

ISSN 2345-0282 (online) http://jssidoi.org/jesi/

2021 Volume 8 Number 3 (March)

http://doi.org/10.9770/jesi.2021.8.3(17)

modern-day venture capital, the current modern form of venture capital appeared in 2011 (Seoudi \& Mahmoud, 2016). In recent times the number of non-Americans VCs has been escalating in KSA (Khan \& Khan, 2020).

According to experts, venture capital is useful for countries like KSA due to the ongoing changes and heavy infrastructure investment initiatives. Furthermore, the government's other several initiatives like the promotion of entrepreneurial activities, incubators, and interest-free loans for startups are important for venture capital growth in the country (MEVCA, 2013). Moreover, in terms of their performance in Saudi Arabia, venture capital has served crucial roles as a mechanism for economic empowerment and development. Gradually, venture capital specializing in SME financing and private equity investments in the Kingdom are becoming prominent. Presently, Saudi Arabia is the biggest economy in the GCC region with many SMEs, most of which focus on retail and service provision. The high number of SMEs in Saudi Arabia suggests that establishing Venture Capital would go a long way in helping the firms fit into the highly competitive market.

The venture capitals in various countries faced many ups and downs. Especially in the previous three decades, the Asian crises, the IT bubble burst, the 2008 financial crisis, and now recent COVID crises remained the general reasons for these challenges apart from other country-specific reasons. Various studies have explored the causes of these challenges faced by venture capitals in different setups. Various authors conducted studies in the context of multiple countries to highlight these challenges and problems. Murray (1992) pointed out the problems with the venture capital firms of the UK. According to the author, even after maturity, the industry's finances remained concentrated in a few portfolio firms, which was the main strategic problem for the venture capital industry. Jones and Mlambo (2013) conducted a study for the South African market. The authors indicated that specialized fund managers' unavailability and general low entrepreneurial skills level are the main hindrance factors for venture capital firms. Scheela and Van Dinh (2004) highlighted the lack of quality investment and excessive regulations as the main challenges of Venture Capital firms in Vietnam. Dauterive and Fok (2004) pointed out the leading venture capital challenges in the Chinese market; according to the study, the strict regulatory environment and capital controls are the main hindrances these VCs face. Similarly, Zhang (2017) also focused on the institutional framework and organizational structure of venture capital investment trust with reference to China; the study suggested some key reforms relating to such firms' ownership structure and independence. There is a number of researches available on the problems and challenges faced by venture capital firms in China; some other studies that focused on China's venture capital industry's challenges include Xia et al. (2001).

Oher studies explore the venture capital issues in other countries like Italy (Rossi, 2015). According to the author, venture capital in Italy focused more on already developed sectors, whereas their interest in the service sector and young innovative firms remained relatively low. Similarly, a study conducted in USA (Aberman, 2009). The author noticed that the private venture capital market was shrinking, and VC firms were not generating a healthy return. It was mainly because some of the newly emerging venture capital managers could not raise enough capital. On the other hand, a very captivating study by Brush et al. (2018) pointed out an exciting aspect of venture capital challenges for the US market. According to the analysis of the study, the business firms led by women were able to attract less funding from venture capital firms compared to the business firms led by men. As mentioned earlier with regard to Saudi Arabia, this study will bring new insights into the problems and challenges faced by Saudi Venture capitalists.

\section{Data and Methodology}

In this study, we used a quantitative approach based on the primary data to examine the problems and challenges of venture capital firms. For this purpose, we used a questionnaire to collect data from various stakeholders. The questionnaire highlights venture capital problems and prospects. For this purpose, our target audience was the venture capitalist managers, entrepreneurs, investors, and bankers to identify the problems and prospects of venture capital in Saudi Arabia. The questionnaire developed for this study has two parts; the first section with open-ended questions to measure the un-aided recall and perceptions towards Venture Capital, and the second section with close-ended questions with a five-point Likert scale. These questions were adapted from earlier studies (Carmines \& Zeller, 1979; Fink \& Litwin, 1995). After drafting the questions, various validity checks 
ENTREPRENEURSHIP AND SUSTAINABILITY ISSUES

ISSN 2345-0282 (online) http://jssidoi.org/jesi/

2021 Volume 8 Number 3 (March)

http://doi.org/10.9770/jesi.2021.8.3(17)

were applied. Five different venture capital experts and university faculty were interviewed for the questionnaire draft. Several questions were added and removed; many items were adjusted based on the recommendations by the jury of experts until we reached a final draft of the questionnaire. It was pilot tested on five venture capitalists, and results were shown to the jury of experts. Open-ended questions were increased to 6 instead of 5, and closeended questions were reduced to 31 instead of 39 questions. After validating the questionnaire, the main data collection was started in three cities, i.e., Riyadh, Jeddah, and Dammam. The sample comprises venture capitalists, entrepreneurs, experts for entrepreneurial finance, bankers, and investors. Table 1 and 2 presents the list of university business incubators and national business incubators participated in this research.

Table 1 List of University Business Incubators participated in this study

\begin{tabular}{|c|c|c|}
\hline No & University Business Incubator & City \\
\hline 1 & Innovation and entrepreneurship center - Business incubator and accelerator, Al-Baha university & Al-Bahah \\
\hline 2 & Najahat - Business incubator, King Faisal University & Al-Hasa \\
\hline 3 & IAU Entrepreneurship center - Business incubator and accelerator, Imam Abdurrahman Bin Faisal University & Dammam \\
\hline 4 & Entrepreneurship institute - King Fahad for University of Petroleum and (KFUPM) & Dammam \\
\hline 5 & Hail university startup accelerator - Business incubator and accelerator, Hail university & Hail \\
\hline 6 & Jnnov8 - Business incubator and accelerator, Jazan University & Jazan \\
\hline 7 & Business Innovation and Entrepreneurship - Business incubator and accelerator, Effat university & Jeddah \\
\hline 8 & Sahabat Alimam - Business incubator, Imam Mohammed bin Saud Islamic University & Madinah \\
\hline 9 & Bab-Al-Madinah - Business incubator \& accelerator, Islamic University of Madinah & Makkah \\
\hline 10 & Wadi Makkah - Business incubator and accelerator, Umm Al-Qura University & Riyadh \\
\hline 11 & Centre of creativity and entrepreneurship - Business incubator \& accelerator, King Abdulaziz University & Riyadh \\
\hline 12 & Innovation and economic development -King Abdullah University of Science of Technology (KAUST) & Riyadh \\
\hline 13 & Hikma incubator, King Abdullah University of Science of Technology (KAUST) & Riyadh \\
\hline 14 & King Salman Institute for Entrepreneurship - Business incubator and accelerator, King Saud University & Taif \\
\hline 15 & Innovation and entrepreneurship center - Business incubator and accelerator, University of Taif &
\end{tabular}

Table 2 List of National Business Incubators participated in this study

\begin{tabular}{|c|c|c|c|c|c|}
\hline No & Business Incubator & City & No & Business Incubator & City \\
\hline 1 & BADIR - King Abdullah City of Science and Technology (KACST) & Riyadh & 11 & FLAT6LABS & Jeddah \\
\hline 2 & Misk 500 - MISK Foundation & Riyadh & 12 & InspireU & Riyadh \\
\hline 3 & 9/10ths - King Abdullah University of Science and Technology (KAUST) & Riyadh & 13 & Tamakkun BA & Riyadh \\
\hline 4 & E3qlha - First women's business incubator & Riyadh & 14 & Entertainment BA & Riyadh \\
\hline 5 & Bab Rizq - Abdullatif Jameel Motors & Riyadh & 15 & I-be Hub & Riyadh \\
\hline 6 & Jeddah Valley & Jeddah & 16 & Inspire & Riyadh \\
\hline 7 & Dhahran techno valley & Dharan & 17 & Startups House & Riyadh \\
\hline 8 & Riyadh Taqnia venture & Riyadh & 18 & Oqal & Riyadh \\
\hline 9 & Riyadh Valley & Riyadh & 19 & Raz & Riyadh \\
\hline 10 & Saudi Credit and Savings bank & Riyadh & 20 & Riyada & Riyadh \\
\hline
\end{tabular}

The most difficult part of the research was to find venture capitalists ready to give time and share their thoughts. There was no consolidated list of venture capitalists available in Saudi Arabia. A strategy was employed in this research to get access to venture capitalists. All university business incubators and national business incubators were contacted to get referrals for their venture capitalists. The strategy was successful, and a significant number of venture capitalists were accessed through referrals. The online questionnaire link was sent to 320 various stakeholders. One hundred sixty-five responses were received, making a response rate of 52\%. In order to improve the quality of data, we have excluded incomplete and inconsistent responses (Rahm \& Do, 2000). Finally, 122 responses were used for further analyses. Table 3 presents the demographic details of the respondents for this research. 
ENTREPRENEURSHIP AND SUSTAINABILITY ISSUES

ISSN 2345-0282 (online) http://jssidoi.org/jesi/

2021 Volume 8 Number 3 (March)

http://doi.org/10.9770/jesi.2021.8.3(17)

Table 3 Respondent's Profile

\begin{tabular}{|c|c|c|c|c|c|}
\hline Gender & Frequenc & Percent & Status & Frequenc & Percent \\
\hline Male & 101 & $83 \%$ & Entrepreneurs & 59 & $48 \%$ \\
\hline Female & 21 & $17 \%$ & Venture Capitalists & 26 & $21 \%$ \\
\hline Total & 122 & $100 \%$ & Business Incubator Experts & 17 & $14 \%$ \\
\hline & & & Bankers \& Investors & 20 & $17 \%$ \\
\hline Age & & & Total & 122 & $100 \%$ \\
\hline Less than 25 years & 12 & $10 \%$ & Education & Frequenc & Percent \\
\hline 25-34 years & 50 & $41 \%$ & Bachelor & 37 & $30 \%$ \\
\hline More than 34 years & 60 & $49 \%$ & Master & $30 \%$ \\
\hline Total & 122 & $100 \%$ & Others & 12 & $10 \%$ \\
\hline
\end{tabular}

\section{Analyses and Results}

For this exploratory study, data were analysed in two steps. Firstly, open-ended questions were analysed to measure the un-aided recall towards venture capital. Secondly, the descriptive analysis was made for close-ended questions to identify the most critical venture capital challenges in Saudi Arabia. Thirdly, exploratory factor analyses were used to summarize the challenges.

\subsection{Qualitative Analysis:}

Data generated during initial interviews and open-ended responses from surveys provided an opportunity to offer qualitative data analysis. Table 4 presents open-ended questions and top three responses for each question with the frequency. Respondents were allowed to give more than one answer for each open-ended question.

Table 4 Qualitative Analysis - VC Challenges in Saudi Arabia

\begin{tabular}{|c|c|c|}
\hline Open Ended Questions & Three Frequent Answers & Frequency \\
\hline What comes to your mind & Highly risky investment /High profit & 65 \\
\cline { 2 - 3 } when you hear "Venture & Entrepreneurship/start-up /opportunities & 58 \\
\cline { 2 - 3 } Capital"? & Funding/capital/money/finance & 33 \\
\hline What is the most & Money; Profit \& Return on Investment & 61 \\
\cline { 2 - 3 } important thing for any & Feasibility; Market Study \& Planning & 39 \\
\cline { 2 - 3 } VC firm? & Idea \& opportunities & 19 \\
\hline What do VC firms expect & Entrepreneur's Personal Characteristics & 63 \\
\cline { 2 - 3 } from entrepreneurs & Good feasibility study & 21 \\
\cline { 2 - 3 } & Relevant experience \& knowledge & 22 \\
\hline \multirow{2}{*}{$\begin{array}{c}\text { What are the most } \\
\text { important problems of VC } \\
\text { firms in Saudi Arabia }\end{array}$} & Lack of appropriate law/legal system/regulations \\
\cline { 2 - 3 } & Venture Capitalist relevant issues & 15 \\
\cline { 2 - 3 } & Lack of good/unique/innovative ideas & 11 \\
\hline
\end{tabular}

The analysis phase was started by analysing open-ended questions and responses received during the study's earlier phases, including interviews and focus groups. Open-ended questions were included in the questionnaire to solicit replies from respondents in their own words and are intended to evoke rich data than is conceivable in close-ended questions or multiple-choice questions. This has helped us to understand the general perceptions of various stakeholders towards VC in Saudi Arabia. Regarding the un-aided call or perception towards 'Venture Capital,' the respondents showed their clarity of mind towards VC that it is a risky investment with higher returns. In another question, they described the most important agenda for any VC firm is profit and return on investment. It shows they are looking for good entrepreneurial projects for investment. In another question about the expectations from entrepreneurs to provide them finance, they expressed entrepreneurial personal characteristics as the major requirement. Personal characteristics listed in the list include multi-skills, credibility, teamwork, creativity \& innovation, quality, planning, seriousness, passion, technical understanding, business understanding, honesty, and risk orientation (high Risk vs. Low Risk). 
ENTREPRENEURSHIP AND SUSTAINABILITY ISSUES

ISSN 2345-0282 (online) http://jssidoi.org/jesi/

2021 Volume 8 Number 3 (March)

http://doi.org/10.9770/jesi.2021.8.3(17)

Table 5 Descriptive Analysis (Frequency Distribution \& Mean) - VC Challenges in Saudi Arabia

\begin{tabular}{|c|c|c|c|c|c|c|c|}
\hline \multirow{3}{*}{ Items } & \multicolumn{7}{|c|}{ Level of Perceived Problem } \\
\hline & \multicolumn{5}{|c|}{ Frequency Distribution } & \multirow{2}{*}{ Total } & \multirow{2}{*}{ M } \\
\hline & 1 & 2 & 3 & 4 & 5 & & \\
\hline Lack of government support for VC & 0 & 8 & 17 & 41 & 56 & 122 & 4.19 \\
\hline Bureaucratic procedures related to $\mathrm{VC}$ & 1 & 9 & 22 & 41 & 49 & 122 & 4.05 \\
\hline Access to angel investors (funding without collateral) & 5 & 8 & 16 & 45 & 48 & 122 & 4.01 \\
\hline Access to VC & 2 & 8 & 26 & 39 & 47 & 122 & 3.99 \\
\hline Lack of Entrepreneur's vision & 6 & 9 & 22 & 37 & 48 & 122 & 3.92 \\
\hline Lack of Entrepreneur's commitment & 6 & 17 & 12 & 40 & 47 & 122 & 3.86 \\
\hline Entrepreneur's sense of insecurity & 5 & 7 & 24 & 50 & 36 & 122 & 3.86 \\
\hline Lack of Entrepreneur's innovation & 6 & 9 & 23 & 42 & 42 & 122 & 3.86 \\
\hline Lack of sound feasibility study & 6 & 9 & 23 & 43 & 41 & 122 & 3.85 \\
\hline Lack of collateral/guarantees & 5 & 11 & 22 & 45 & 39 & 122 & 3.84 \\
\hline Lack of proper business plan & 6 & 9 & 24 & 45 & 38 & 122 & 3.82 \\
\hline Lack of understanding - SME rules \& procedure & 9 & 10 & 21 & 42 & 40 & 122 & 3.77 \\
\hline Lack of government support for entrepreneurs & 6 & 13 & 23 & 41 & 39 & 122 & 3.77 \\
\hline Limited 'Stock of knowledge' about VC & 9 & 13 & 22 & 41 & 37 & 122 & 3.69 \\
\hline Lack of R\&D in KSA & 6 & 10 & 33 & 47 & 26 & 122 & 3.63 \\
\hline Lack of 'Spin-off' culture (company on campus) & 13 & 14 & 22 & 34 & 39 & 122 & 3.59 \\
\hline Lack of Entrepreneurial Aspirations & 7 & 21 & 19 & 45 & 30 & 122 & 3.57 \\
\hline Applicant's Technical knowhow & 7 & 12 & 38 & 35 & 30 & 122 & 3.57 \\
\hline Lack of Entrepreneurial Attitudes & 11 & 15 & 28 & 30 & 38 & 122 & 3.57 \\
\hline Start-up Company registration (patent registration) & 11 & 9 & 31 & 43 & 28 & 122 & 3.56 \\
\hline Lack of Entrepreneurial Activities & 6 & 15 & 32 & 47 & 22 & 122 & 3.52 \\
\hline Applicant's Risk orientation (Risk taker VS Risk averse) & 11 & 17 & 28 & 33 & 33 & 122 & 3.49 \\
\hline Access to banking facilities (bank guarantees, Forex) & 9 & 20 & 28 & 38 & 27 & 122 & 3.44 \\
\hline Applicant's relevant Experience & 6 & 25 & 31 & 29 & 31 & 122 & 3.44 \\
\hline Lack of education of Entrepreneur & 8 & 17 & 36 & 40 & 21 & 122 & 3.40 \\
\hline Applicant seeking public sector jobs & 13 & 23 & 25 & 30 & 31 & 122 & 3.35 \\
\hline High Competition (industry competitive forces) & 16 & 18 & 27 & 39 & 22 & 122 & 3.27 \\
\hline Applicant's Educational background & 18 & 16 & 35 & 35 & 18 & 122 & 3.16 \\
\hline Cultural availability of family support & 14 & 23 & 32 & 36 & 17 & 122 & 3.16 \\
\hline Access to SME Authority & 21 & 27 & 37 & 26 & 11 & 122 & 2.83 \\
\hline Applicant's Family background & 39 & 17 & 37 & 16 & 13 & 122 & 2.57 \\
\hline
\end{tabular}

Regarding the most important VC problems in Saudi Arabia, 'lack of clear rules and regulation' for VC firms in Saudi Arabia has emerged as the most frequent answer, which is approximately $19 \%$ of all answers. However, according to respondents, the second highest problem is the 'issues relevant to the Venture Capital firm itself,' which was repeated 15 times (13\%). On the other hand, according to respondents, both the 'investor related issues' and 'lack of an appropriate system for VC firm' are also considerable problems faced by VC firm; the answer was repeated by four times representing $3 \%$ of all answers.

\subsection{Descriptive Analysis:}

Closed-ended questions with five-point Likert scale responses were analysed using SPSS. The objective was to identify the most critical challenges of VC in Saudi Arabia. Table 5 presents frequency distribution and mean comparisons of all responses. The top three items based on mean comparisons include 'Lack of government support for $\mathrm{VC}^{\prime}(\mathrm{M}=4.19)$; 'Bureaucratic procedures related to $\mathrm{VC}^{\prime}(\mathrm{M}=4.05)$ and 'Access to angel investors (funding without collateral)' $(\mathrm{M}=4.01)$. 


\section{ENTREPRENEURSHIP AND SUSTAINABILITY ISSUES}

ISSN 2345-0282 (online) http://jssidoi.org/jesi/

2021 Volume 8 Number 3 (March)

http://doi.org/10.9770/jesi.2021.8.3(17)

\subsection{Factor Analysis:}

Exploratory factor analyses, using the maximum likelihood method of extraction and varimax rotation, was used to determine the factor structure of 31 items related to venture capital in Saudi Arabia. The factor loading criteria were applied, which required that (a) a factor must have at least two salient item loadings greater than 0.3, (b) individual items must have at least one-factor loading greater than 0.3 , and (c) any item loading on more than one factor when the final solution is obtained will be placed only in the factor on which it loads most highly. Finally, the six-factor solution was obtained, meeting all criteria for successful exploratory factor analysis presented in Table 6. Based on results shown in the table below as a result of the factor analysis technique in SPSS software.

Table 6 Exploratory Factor Analyses - VC Challenges in Saudi Arabia

\begin{tabular}{|c|c|c|c|c|c|c|}
\hline \multirow[b]{2}{*}{ Items } & \multicolumn{6}{|c|}{ Factors } \\
\hline & $\begin{array}{c}\text { Entrepre } \\
\text { neurial } \\
\text { Ecosyste }\end{array}$ & $\begin{array}{c}\text { Entrepr } \\
\text { eneurial } \\
\text { Culture }\end{array}$ & $\begin{array}{c}\text { Entrepr } \\
\text { eneurial } \\
\text { Attitud }\end{array}$ & $\begin{array}{l}\text { Entrepr } \\
\text { eneurial } \\
\text { Mindset }\end{array}$ & $\begin{array}{l}\text { Entrepr } \\
\text { eneurial } \\
\text { Finance }\end{array}$ & $\begin{array}{l}\text { Entrepr } \\
\text { eneurial } \\
\text { Plannin }\end{array}$ \\
\hline Start-up Company registration (patent registration) & 685 & & & & & \\
\hline Bureaucratic procedures related to $\mathrm{VC}$ & .678 & & & & & \\
\hline Lack of government support for entrepreneurs & .661 & & & & & \\
\hline Lack of government support for VC & .590 & & & & & \\
\hline High Competition (industry competitive forces) & .558 & & & & & \\
\hline Limited 'Stock of knowledge' about VC & .527 & & & & & \\
\hline Lack of R\&D in KSA & .475 & & & & & \\
\hline Lack of understanding - SME rules \& procedure & .407 & & & & & \\
\hline Lack of 'Spin-off' culture (company on campus) & & .769 & & & & \\
\hline Cultural availability of family support & & .725 & & & & \\
\hline Entrepreneur's sense of insecurity & & .705 & & & & \\
\hline Lack of entrepreneur's innovation & & .622 & & & & \\
\hline Lack of collateral/guarantees & & .506 & & & & \\
\hline Lack of entrepreneurial attitudes & & & .737 & & & \\
\hline Lack of entrepreneurial aspirations & & & .729 & & & \\
\hline Lack of entrepreneurial activities & & & .626 & & & \\
\hline Lack of entrepreneur's vision & & & 616 & & & \\
\hline Lack of entrepreneur's education & & & .545 & & & \\
\hline Lack of entrepreneur's commitment & & & .368 & & & \\
\hline Applicant's Technical know-how & & & & .718 & & \\
\hline Applicant seeking public sector jobs & & & & .715 & & \\
\hline Applicant's relevant Experience & & & & .672 & & \\
\hline Applicant's Risk orientation (Risk taker VS Risk averse) & & & & .554 & & \\
\hline Access to SME Authority & & & & & .733 & \\
\hline Access to angel investors (funding without collateral) & & & & & .693 & \\
\hline Access to $\mathrm{VC}$ & & & & & .530 & \\
\hline Access to banking facilities (bank guarantees, Forex etc.) & & & & & .487 & \\
\hline Applicant's Family background & & & & & & .775 \\
\hline Applicant's Educational background & & & & & & .540 \\
\hline Lack of sound feasibility study & & & & & & .475 \\
\hline Lack of proper business plan & & & & & & .442 \\
\hline
\end{tabular}

These factors were named; accordingly, (a) entrepreneurial ecosystem, (b) entrepreneurial culture, (c) entrepreneurial attitudes, (4) entrepreneurial mindset, (5) entrepreneurial finance, (6) entrepreneurial planning. Factor 1 had an eigenvalue of 5.32, and it accounted for $22.12 \%$ of the variance. It had loadings on items like startup company registration (patent registration); bureaucratic procedures related to VC, lack of government support for entrepreneurs; lack of government support for VC; high competition (industry competitive forces); limited 'stock of knowledge' about VC; lack of R\&D in KSA; lack of understanding - SME rules \& procedures. It was named as Entrepreneurial Ecosystem. Factor 2 had an eigenvalue of 3.11, and it accounted for $11.14 \%$ of the 


\section{ENTREPRENEURSHIP AND SUSTAINABILITY ISSUES}

ISSN 2345-0282 (online) http://jssidoi.org/jesi/

2021 Volume 8 Number 3 (March)

http://doi.org/10.9770/jesi.2021.8.3(17)

variance with loadings on items including lack of 'spin-off' culture (company on campus), cultural availability of family support, entrepreneur's sense of insecurity, lack of entrepreneur's innovation, lack of collateral/guarantees. It was named as Entrepreneurial Culture. Factor 3 had an eigenvalue of 2.81, and it accounted for $7.22 \%$ of the variance with loadings on items as lack of entrepreneurial attitudes, lack of entrepreneurial aspirations, lack of entrepreneurial activities, lack of entrepreneur's vision, lack of entrepreneur's education, lack of entrepreneur's commitment. It was labeled as Entrepreneurial Attitudes. Factor 4 had an eigenvalue of 1.36, and it accounted for $7.21 \%$ of the variance with loadings on items like applicant's technical know-how, applicant seeking public sector jobs, applicant's relevant experience, risk orientation (risk taker vs Risk-averse). It was labeled as an Entrepreneurial Mindset. Factor 5 had an eigenvalue of 1.65, and it accounted for $6.86 \%$ of the variance with loadings on items like access to SME authority, access to angel investors (funding without collateral), access to VC, access to banking facilities (bank guarantees, Forex etc.) It was named as Entrepreneurial Finance. Factor 6 had an eigenvalue of 1.47, and it accounted for $4.75 \%$ of the variance with loadings on items like applicant's family background, applicant's educational background (relevant background), lack of sound feasibility study, lack of a proper business plan. It was named Entrepreneurial Planning.

\section{Conclusions and Recommendations}

The role of venture capital as a useful contributor to corporate and economic growth is well documented in the literature (Rind, 1981; Samila \& Sorenson, 2011). Furthermore, the venture capital role in entrepreneurship development in developing \& emerging economies is also well discussed (Bonini \& Capizzi, 2019; Herrington et al., 2010; Tian, 2012). In performing this valuable role, the venture capital firms, as a form of business, also face various types of challenges. Some of these challenges are relating to the rules and regulations, some relating to the local business environment, and others relate to the entrepreneurial deficiencies in the economy (Dauterive \& Fok, 2004; Jones \& Mlambo, 2013; Scheela \& Van Dinh, 2004). In this study, we investigated the problems and challenges faced by venture capital firms in KSA. The country is an important emerging economy in the GCC region and going through an economic transformation. Efforts are going on to shift the country's economic dependence from oil to the non-oil sector, and small businesses and entrepreneurial growth is one of the areas that is stressed. Therefore, the role of venture capitals becomes critical to financing the emerging business activity in the country. Similarly, with venture capital firms' growing activity, they face various types of challenges and problems.

The study used a quantitative approach based on the primary data to examine the problems and challenges of venture capital firms. We developed a questionnaire to collect data from various stakeholders and highlights venture capital problems and prospects in KSA. We target the venture capitalist managers, entrepreneurs, investors, and bankers as respondents. The data collection was collected in three big cities of KSA, i.e., Riyadh, Jeddah, and Dammam.

The study investigates the main problems/challenges faced by venture capital firms in Saudi Arabia. We pursue to find these prospects and limitations of venture capital from all stakeholders, such as bankers, government, and investors, entrepreneurs, and funding institutions to obtain a 360-degree view. The study applied statistical techniques like factor analysis using SPSS. In the finding of the study, we categorized these challenges into six broader factors, including (1) entrepreneurial ecosystem, (2) entrepreneurial culture, (3) entrepreneurial attitudes, (4) entrepreneurial mindset, (5) entrepreneurial finance, (6) entrepreneurial planning. The challenges identified in these factors are further discussed in the results.

Qualitative and factor analysis techniques were applied using SPSS software. The results of the study revealed many interesting facts. Under the entrepreneurial ecosystem, the lack of government support for entrepreneurs, lack of government support for VC, lack of research \& development in KSA remained the significant challenges. Under entrepreneurial culture, the entrepreneur's sense of insecurity, lack of entrepreneur's innovation are the main problems. Lack of entrepreneurial attitudes, lack of entrepreneurial aspirations remained the main issues under the main head of entrepreneurial attitude. Similarly, issues like the applicant's technical know-how, the applicant seeking public sector jobs, the applicant's relevant experience, and risk orientation 


\section{ENTREPRENEURSHIP AND SUSTAINABILITY ISSUES}

ISSN 2345-0282 (online) http://jssidoi.org/jesi/

2021 Volume 8 Number 3 (March)

http://doi.org/10.9770/jesi.2021.8.3(17)

appeared under the Entrepreneurial Mindset factor. Moreover, under the Entrepreneurial Finance factor, problems like access to SME authority, access to banking facilities for bank guarantees, etc., purpose were identified. Finally, challenges like lack of sound feasibility study, lack of a proper business plan appeared under the Entrepreneurial Planning factor. Overall, our study results are in line with previous research see (Dauterive \& Fok, 2004; Jones \& Mlambo, 2013; Scheela \& Van Dinh, 2004).

\subsection{Recommendations}

The study also presents several recommendations. Firstly, government agencies should understand that venture capital and angel investors are different from conventional banks, and VC firms should get a separate set of laws and regulations. Ministries take actions to eliminate important obstacles and develop more flexible rules and regulations towards VC. Secondly, there is a need to improve the awareness and understanding of VC. All universities, especially business schools teaching entrepreneurship, should include VC as part of the entrepreneurship curriculum. Furthermore, the ministry of education should re-organize the entrepreneurship courses in all universities to be more focused on Venture Capital as an essential pillar for the entrepreneurship domain. Finally, entrepreneurs should also improve their commitments to get the confidence of finance institutions and decision-makers. They should show professionalism, seriousness, commitment, and transparency for funding institutions.

\subsection{Limitations}

This research is an outcome of overcoming many limitations. These limitations include lack of resource relevant to venture capital in Saudi Arabia, availability of a limited number of entrepreneurship centers in Saudi Arabia. Moreover, difficulty to access entrepreneur's database from other institutions is another limitaion. Furthermore, there is no government authority to regulate venture capital; no venture capital firms database exists in Saudi Arabia.

\subsection{Need for further research}

This exploratory research has been conducted as the first research on Venture Capital and its problems, challenges, and prospects in KSA. We still feel that there is a lot more to be done in this field. Firstly, there is a need for indigenous research on rules and regulations needed to support VC in Saudi Arabia. The shortage of this type of research makes the study more inevitable for many scholars. There are several dimensions for future research areas such as Venture Capital firm role in Vision 2030, venture capital development agency in Saudi Arabia.

\section{References}

Aberman, J. (2009). The decline of the United States venture capital industry: What the federal government should do about it. Amplifier Ventures. http://www.innovationamerica.us/images/stories/pdf/abermanvcwhitepaper.pdf

Bellavitis, C., Filatotchev, I., Kamuriwo, D. S., \& Vanacker, T. (2017). Entrepreneurial finance: new frontiers of research and practice: Editorial for the special issue Embracing entrepreneurial funding innovations. In: Taylor \& Francis. https://doi.org/10.1080/13691066.2016.1259733

Bocken, N. M. (2015). Sustainable venture capital-catalyst for sustainable start-up success? Journal of Cleaner Production, 108, $647-658$. Bonini, S., \& Capizzi, V. (2019). The role of venture capital in the emerging entrepreneurial finance ecosystem: future threats and opportunities. Venture Capital, 21(2-3), 137-175. https://doi.org/10.1080/13691066.2019.1608697

Bonnet, C., \& Wirtz, P. (2011). Investor type, cognitive governance and performance in young entrepreneurial ventures: A conceptual framework. https://halshs.archives-ouvertes.fr/halshs-00642737/document 


\section{ENTREPRENEURSHIP AND SUSTAINABILITY ISSUES}

ISSN 2345-0282 (online) http://jssidoi.org/jesi/

2021 Volume 8 Number 3 (March)

http://doi.org/10.9770/jesi.2021.8.3(17)

Brush, C., Greene, P., Balachandra, L., \& Davis, A. (2018). The gender gap in venture capital-progress, problems, and perspectives. Venture Capital, 20(2), 115-136. https://doi.org/10.1080/13691066.2017.1349266

Campani, C. H., Maranho, F. S., Alvarenga, H. D. A., Lima, M. B. A., \& Guimaraes, R. S. (2016). Antera: The challenges of private equity and venture capital management. Administracao-Ensino E Pesquisa, 17(3), 509-535. https://doi.org/10.13058/raep.2016.v17n3.470

Capizzi, V., \& Carluccio, E. M. (2016). Competitive Frontiers in Equity Crowdfunding: The Role of Venture Capitalists and Business Angels in the Early-Stage Financing Industry. In Crowdfunding for SMEs (pp. 117-157): Springer.

Carmines, E. G., \& Zeller, R. A. (1979). Reliability and validity assessment (Vol. 17): Sage publications.

Cornelius, B. (2005). The institutionalisation of venture capital. Technovation, 25(6), 599-608.

Dauterive, J., \& Fok, W. (2004). Venture capital for China: opportunities and challenges. Managerial Finance, 30(2), 3-15. https://doi.org/10.1108/03074350410768877

Dossani, R., \& Kenney, M. (2002). Creating an environment for venture capital in India. World Development, 30(2), $227-253$.

Fink, A., \& Litwin, M. S. (1995). How to measure survey reliability and validity (Vol. 7): Sage.

Gilson, R. J. (2003). Engineering a venture capital market: lessons from the American experience. Stanford Law Review, $1067-1103$.

Gu, W., \& Qian, X. (2019). Does venture capital foster entrepreneurship in an emerging market? Journal of Business Research, 101, 803810. https://doi.org/10.1016/j.jbusres.2018.12.011

Herrington, M., Kew, J., Kew, P., \& Monitor, G. E. (2010). Tracking entrepreneurship in South Africa: A GEM perspective: Graduate School of Business, University of Cape Town South Africa.

Jones, M., \& Mlambo, C. (2013). Early-stage venture capital in South Africa: Challenges and prospects. South African Journal of Business Management, 44(4), 1-12. https://doi.org/10.4102/sajbm.v44i4.164

Khan, M. K., \& Khan, M. B. (2020). Research, Innovation and Entrepreneurship in Saudi Arabia: Vision 2030: Routledge. ISBN 9781138488533, $192 \mathrm{p}$.

Mamonov, S., Malaga, R., \& Rosenblum, J. (2017). An exploratory analysis of Title II equity crowdfunding success. Venture Capital, 19(3), 239-256.

Marchand, F. I. (2016). Crowdfunding Real Estate: Institutions and Markets. An Institutional Comparison on the Growth-patterns and Behaviour of Crowdfunding Real Estate Markets in the Netherlands and United States. https://repository.tudelft.nl/islandora/object/uuid\%3A785a36c8-2a5b-4d5f-84a2-b60093491551

MEVCA. (2013). Venture Capital in the Middle East and North Africa Retrieved from https://www.academia.edu/6760725/Venture_Capital_in_the_Middle_East_and_North_Africa_Report_Table_of_Contents?auto=download

Murray, G. C. (1992). A Challenging Marketplace For Venture Capital. Long Range Planning, 25(6), 79-86. https://doi.org/10.1016/0024$\underline{6301(92) 90173-y}$

Rahm, E., \& Do, H. H. (2000). Data cleaning: Problems and current approaches. IEEE Data Eng. Bull., 23(4), 3-13.

Rind, K. W. (1981). The role of venture capital in corporate development. Strategic Management Journal, 2(2), 169-180.

Rossi, M. (2015). The role of venture capital funds in financing innovation in Italy. Constraints and challenges for innovative small firms. International Journal of Globalisation and Small Business, 7(2), 162-180.

Sahlman, W. A. (1990). The structure and governance of venture-capital organizations. Journal of financial economics, 27(2), 473-521.

Samila, S., \& Sorenson, O. (2011). Venture capital, entrepreneurship, and economic growth. The Review of Economics and Statistics, 93(1), 338-349. 


\section{ENTREPRENEURSHIP AND SUSTAINABILITY ISSUES}

ISSN 2345-0282 (online) http://jssidoi.org/jesi/

2021 Volume 8 Number 3 (March)

http://doi.org/10.9770/jesi.2021.8.3(17)

Samuel, J. (2017). Global VC investment remains strong - mega deals lead the way. Retrieved from Retrieved from https://home.kpmg.com/xx/en/home/media/press-releases/2017/10/global-vc-investment-strong-kpmg-venture-pulse-q3-2017.html

Scheela, W., \& Chua, R. (2003). Venture capital in a Developing Country: the Case of the Philippines. Paper presented at the 7th International Conference on Global Business and Economic Development, January

Scheela, W., \& Van Dinh, N. (2004). Venture capital in a transition economy: The case of Vietnam. Venture Capital: An International Journal of Entrepreneurial Finance, 6(4), 333-350.

Seoudi, I., \& Mahmoud, S. (2016). Public Policy for Venture Capital: A Comparative Study of Emirates, Saudi Arabia and Egypt. Review of Business \& Finance Studies, 7(1), 19-42.

Tian, X. (2012). The role of venture capital syndication in value creation for entrepreneurial firms. Review of Finance, 16(1), $245-283$.

Van Osnabrugge, M. (2000). A comparison of business angel and venture capitalist investment procedures: an agency theory-based analysis. Venture Capital: An International Journal of Entrepreneurial Finance, 2(2), 91-109.

Xia, E. J., Liu, L. P., Yan, X. X. (2001). Orient Academic Forum, P., \& Orient Academic Forum, P. A study on problems and countermeasure of Venture Capital of China. https://file.scirp.org/pdf/18-1.8.12.pdf

Zhang, C. (2017). Venture capital investment trusts in China: legal framework, challenges, and reform. Trusts \& Trustees, 23(7), 806-822. https://doi.org/10.1093/tandt/ttx100 


\section{ENTREPRENEURSHIP AND SUSTAINABILITY ISSUES}

ISSN 2345-0282 (online) http://jssidoi.org/jesi/

2021 Volume 8 Number 3 (March)

http://doi.org/10.9770/jesi.2021.8.3(17)

Dr. Kamran SIDDIQUI is an Associate Professor of Marketing and Entrepreneurship at the College of Business Administration, Imam Abdulrahman Bin Faisal University, Saudi Arabia. Research interests: entrepreneurship, business incubators and accelerators, entrepreneurial marketing, venture capital.

ORCID ID: 0000-0002-5724-0991

Dr. Mohammad EMAD AL-SHAIKH is an Assistant Professor of Entrepreneurship at College of Business Administration, Imam Abdulrahman Bin Faisal University, Saudi Arabia. He is also head of the IAU entrepreneurship unit and business incubator. Research interests: entrepreneurship, business incubators and accelerators, and entrepreneurial marketing

ORCID ID: 0000-0003-4545-3938

Dr. Ishtiaq Ahmed BAJWA is an Assistant Professor of Finance at College of Business Administration, Imam Abdulrahman Bin Faisal University, Saudi Arabia. Research interests: entrepreneurial finance, venture capital, and fin-tech.

ORCID ID: 0000-0001-5296-0028

Omar ALENZI is a graduate student at the College of Business Administration, Imam Abdulrahman Bin Faisal University, Saudi Arabia. ORCID ID: 0000-0001-6529-8264

Make your research more visible, join the Twitter account of ENTREPRENEURSHIP AND SUSTAINABILITY ISSUES: @Entrepr69728810

Copyright (C) 2021 by author(s) and VsI Entrepreneurship and Sustainability Center

This work is licensed under the Creative Commons Attribution International License (CC BY).

http://creativecommons.org/licenses/by/4.0/

c) (i) Open Access 